\title{
Pengaruh Computer Anxiety, Computer Attitude, Dan Computer Self Efficacy, Kondisi Yang Memfasilitasi Pemakai, Dan Faktor Sosial Terhadap Minat Mahasiswa Komputerisasi Akuntansi Menggunakan Software Akuntansi
}

\author{
Fachroh Fiddin ${ }^{1}$, Muhammad Arief ${ }^{2}$ \\ ${ }^{1}$ Program Studi Akuntansi Keuangan Publik, Politeknik Negeri Bengkalis \\ 2Program Studi Administrasi Bisnis, Politeknik Negeri Bengkalis \\ Email: fachroh1@gmail.com1 , muhammad_arief@yahoo.co.id²
}

\begin{abstract}
Today's accounting transformation requires that all processes must be Real-Time and Integrated Reporting, one of which is calculating debit credit and closing the books in the system and minimal use of paper in the transaction documentation process (Paperless). This study is to see the effect of computer anxiety, computer attitude, computer self-efficacy, facilitating conditions, and social factors on student interest in using accounting software in the accounting learning process. This type of research is quantitative research and the data is obtained by distributing questionnaires in which the sample data is accounting students who are taking accurate accounting computer courses., Data analysis was carried out with Regression Analysis, which consisted of validity test, reliability test, normality test, multiple linear regression test. The results showed that computer anxiety and social factors did not affect students' interest in using accounting software in the accounting learning process. Meanwhile, computer attitude, computer self-efficacy, and conditions that facilitate users affect students' interest in using accounting software in the accounting learning process.
\end{abstract}

Keywords: Computer Anxiety, Attitude, Self Efficacy, Facilitating Conditions, Social Factors, Interests, Accounting Software, Accounting Learning

\section{PENDAHULUAN}

Transformasi digital dalam akuntansi adalah penerapan kemampuan digital kepada fungsi, proses, aktivitas/kinerja, dan jasa akuntansi untuk meningkatkan efesiensi dan transparansi, mengurangi beban biaya, meningkatkan kepercayaan masyarakat, mengelola risiko dan membuka peluang ekonomi baru di era digital khususnya revolusi industri 4.0. Transformasi bidang akuntansi dapat dilihat yang sebelumnya perhitungan debit kredit dilakukan secara manual, pengumpulan bukti fisik harus berupa kertas, working paper yang bertumpuk dan proses tutup buku dilakukan secara manual. Akuntansi jaman sekarang mengharuskan real time dan integrated reporting dalam proses akuntansi itu sendiri, penggunaan dokumen secara digital (paperless) pengelohan data dengan big data analytics dan ditampilkan lebih menarik, insighfull melalui data visualization.

Menghadapi era industri 4.0 pengelola pendidikan juga harus berbenah dalam menyiapkan lulusan yang kompeten, penguasaan sumber daya teknologi digital agar mampu bersaing di era distrupsi teknologi. Salah satu upaya yaitu menggunakan komputer akuntansi dalam setiap proses pembelajaran akuntansi. Jika sebelumnya proses pembelajaran dilakukan secara manual dengan membuat working paper, posting, jurnal penutup dilakukan secara manual, maka dengan penggunaan komputer akuntansi semua hal tersebut dapat dilakukan secara otomatis. 
Program studi akuntansi keuangan publik Politeknik Negeri Bengkalis salah satu prodi yang melakukan pembelajaran akuntansi yang terletak pesisir terluar pulau Sumatra. Dengan demografi mahasiswa lebih banyak berasal daerah pesisir dan infrastruktur yang masih belum memadai khususnya teknologi sistem informasinya. Pada Prodi Akuntansi Keuangan Publik telah mengantisipasi perubahan teknologi dengan memasukkan mata kuliah komputer akuntansi kepada mahasiswa dengan penggunaan software akuntansi dalam proses pembelajaran sehingga secara tidak langsung mahasiswa dituntut untuk memiliki keahlian serta menguasai software akuntansi tersebut. Namun karena porsi untuk mata kuliah ini sedikit menyebabkan keahlian mahasiswa dalam menggunakan software akuntansi yang diajarkan tidak signifikan, sehingga menurunkan minat mahasiswa akuntansi dalam menggunakan software akuntansi. Hal disebabkan masih banyak mahasiswa akuntansi yang belum mengerti mengenai penggunaan software akuntansi, sehingga mahasiswa akuntansi merasa tidak nyaman dalam menggunakan software akuntansi.

Terdapat beberapa aspek beberapa aspek mengenai faktor yang mempengaruhi minat seseorang dalam menggunakan sebuah sistem seperti computer anxiety, computer attitude, computer self efficacy, kondisi yang memfasilitasi dan faktor sosial. Computer anxiety merupakan tingkat kecemasan/kegelisahan individu saat individu tersebut menggunakan komputer sehingga menimbulkan rasa takut tidak bisa menggunakan komputer baik itu dimasa sekarang maupun dimasa mendatang. Computer attitude merupakan perilaku individu terhadap komputer karena manfaat yang diperoleh dalam penggunaan komputer itu sendiri. Computer self efficacy menurut Compeau dan Higgins didefinisikan penilaian kapabilitas dan keahlian individu untuk melakukan tugas-tugas yang berhubungan dengan teknologi informasi. Kondisi yang memfasilitasi pemakai merupakan tingkat keyakinan individu bahwa infrastruktur organisasi maupun dukungan teknis dan non teknis dari tenaga ahli dalam pengoperasian sistem informasi disuatu organisasi telah memadai untuk penggunaan sistem informasi sehingga mendorong minat individu untuk menggunakan sistem informasi yang ada didalam organisasi. Faktor sosial merupakan tingkat keyakinan seorang individu untuk menggunakan sistem informasi dipengaruhi faktor lingkungan sosial ekstenal dan internal individu serta image yang diperoleh ketika akan menggunakan sistem informasi sehingga mendorong minat individu untuk menggunakan sistem informasi dalam organisasi.

Berdasarkan latar belakang diatas maka penulis ingin meneliti bagaimana pengaruh computer anxiety, computer attitude, computer self efficacy, kondisi yang memfasilitasi pemakai dan faktor sosial terhadap minat mahasiswa menggunakan software akuntansi pada mahasiswa Prodi Akuntansi Keuangan Publik Politeknik Negeri Bengkalis.

\section{METODE PENELITIAN}

Jenis penelitian yang digunakan adalah penelitian kuantitatif. Objek dan lokasi penelitian yaitu mahasiswa akuntansi prodi akuntansi keuangan publik pada Politeknik Negeri Bengkalis. Teknik penentuan sampel menggunakan Judgment sampling dimana metode penentuan sampel dengan pertimbangan tertentu sesuai kriteria peneliti. Metode pengumpulan data yaitu dengan menyebarkan kuesioner. Sedangkan responden dalam penelitian ini yaitu mahasiswa yang sedang mengambil mata kuliah komputer akuntansi dengan aplikasi software accurate. Analisis data dilakukan dengan Analisis Regresi, yang terdiri dari uji validitas, uji reliabilitas, uji normalitas, uji regresi linier berganda.

\section{HASIL DAN PEMBAHASAN}

\section{Data Karakteristik Responden}

Total responden berjumlah 80 orang mahasiswa akuntansi yang sedang belajar menggunakan komputer akuntansi dengan software accurate. Berikut data responden sebaran responden dalam penelitian ini dapat diliat pada tabel dibawah ini : 
Tabel 3.1

Profil Responden Berdasarkan Jenis Kelamin

\begin{tabular}{|c|c|c|c|}
\hline No & \multicolumn{2}{|c|}{ Jenis Kelamin Jumlah } & Perbandingan \\
\hline 1 & Laki-Laki & 8 & $10 \%$ \\
\hline 2 & Perempuan & 72 & $\frac{90 \%}{100 \%}$ \\
\hline
\end{tabular}

Dari hasil perolehan data isian kuisioner responden, selanjutnya data penelitian akan digunakan untuk mengetahui faktor Computer Anxiety (X1), Computer Attitude (X2), Computer Self Efficacy (X3), Kondisi yang memfasilitasi Pemakai (X4) dan Faktor Sosial (X5) serta Minat Menggunakan ( $\mathrm{Y})$.

\section{Statistik Deskriptif}

Statistik deskriptif variabel penelitian digunakan untuk memberikan gambaran tentang tanggapan responden terhadap variabel-variabel penelitian (Computer Anxiety, Computer Attitude, Computer Self Efficacy, Kondisi yang memfasilitasi pemakai, faktor sosial dan minat menggunakan software akuntansi). Deskripsi data masing-masing variabel secara rinci dapat dilihat dalam Tabel 3.2 berikut:

Tabel 3.2

Descriptive Statistics variabel minat menggunakan software akuntansi

\begin{tabular}{cccccc}
\hline & N & \multicolumn{1}{c}{ Minimum Maximum } & Mean & Std. Deviation \\
\hline M1 & 80 & 3 & 5 & 4,40 &, 565 \\
M2 & 80 & 2 & 5 & 4,25 &, 738 \\
M3 & 80 & 3 & 5 & 4,05 &, 727 \\
M4 & 80 & 3 & 5 & 4,23 &, 729 \\
M5 & 80 & 2 & 5 & 3,98 &, 616 \\
M6 & 80 & 2 & 5 & 3,68 &, 808 \\
M7 & 80 & 3 & 5 & 4,42 &, 522 \\
M8 & 80 & 3 & 5 & 4,11 &, 636 \\
M9 & 80 & 3 & 5 & 4,36 &, 621 \\
\hline Valid N & 80 & \multicolumn{5}{c}{} \\
(listwise) & 85
\end{tabular}

Dari tabel 3.3 diatas beberapa butir pernyataan mengenai minat mahasiswa menggunakan software akuntansi secara rata-rata $>3$, disini responden cenderung setuju dalam menggunakan software akuntansi dalam kegiatan sehari seperti proses pembelajaran, membuat laporan dibandingkan dengan cara manual. 
Tabel 3.3

Descriptive Statistics variabel computer anxiety

\begin{tabular}{cccccc}
\hline & $\mathrm{N}$ & Minimum & Maximum & Mean & Std. Deviation \\
\hline AX1 & 80 & 1 & 5 & 2,58 & 1,524 \\
AX2 & 80 & 1 & 5 & 2,31 & 1,154 \\
AX3 & 80 & 1 & 4 & 1,90 & 1,014 \\
AX4 & 80 & 1 & 5 & 3,24 & 1,265 \\
AX5 & 80 & 1 & 5 & 2,74 & 1,076 \\
AX6 & 80 & 1 & 5 & 3,94 & 1,276 \\
AX7 & 80 & 1 & 5 & 2,20 & 1,095 \\
AX8 & 80 & 1 & 4 & 2,01 & 1,108 \\
AX9 & 80 & 1 & 5 & 2,08 & 1,220 \\
AX10 & 80 & 2 & 5 & 4,25 &, 803 \\
AX11 & 80 & 2 & 5 & 4,20 &, 802 \\
AX12 & 80 & 2 & 5 & 4,36 &, 889 \\
AX13 & 80 & 2 & 5 & 4,49 &, 827 \\
AX14 & 80 & 3 & 5 & 4,68 &, 522 \\
AX15 & 80 & 3 & 5 & 4,73 &, 477 \\
AX16 & 80 & 2 & 5 & 4,66 &, 615 \\
AX17 & 80 & 2 & 5 & 4,36 &, 733 \\
\hline Valid N & 80 & \multicolumn{5}{c}{} \\
(listwise) & & \multicolumn{5}{c}{}
\end{tabular}

Sumber : Data Olahan, 2021

Pada tabel 3.4 dapat dilihat bahwa beberapa item pernyataan mengenai ketakutan mahasiswa menggunakan software akuntansi seperti item pernyataan 1, 2, 3, 4, 5, 7, 8, 9 menunjukkan hasil secara rata-rata $>1$, hasil ini menunjukkan hampir semua mahasiswa akuntansi keuangan publik tidak mengalami kecemasan dalam menggunakan software akuntansi. Sedangkan item pernyataan ke 6 menunjukkan mahasiswa kurang memahami aspek teknik komputer dan pada item pernyataan ke 10, mahasiswa kuatir ketika menggunakan komputer akan menjadi tergantung dan akan kehilangan beberapa kemampuan berpikir. Selanjutnya untuk antisipasi kegelisahan terhadap komputer hasil analisis menunjukkan $>4$, hasil ini menujukkan mampu mengantisipasi kegelisahan dalam menggunakan komputer akuntansi khususnya software akuntansi accurate.

Tabel 3.4

Descriptive Statistics Variabel Computer Attitude

\begin{tabular}{cccccc}
\hline & $N$ & Minimum & Maximum & Mean & $\begin{array}{c}\text { Std. } \\
\text { Deviation }\end{array}$ \\
\hline AT1 & 80 & 1 & 5 & 3,41 & 1,338 \\
AT2 & 80 & 1 & 5 & 3,85 & 1,115 \\
AT3 & 80 & 1 & 5 & 2,14 & 1,052 \\
AT4 & 80 & 1 & 5 & 2,19 & 1,045 \\
AT5 & 80 & 1 & 5 & 2,79 & 1,280 \\
AT6 & 80 & 1 & 5 & 2,60 & 1,249 \\
AT7 & 80 & 1 & 5 & 3,02 & 1,253 \\
AT8 & 80 & 1 & 5 & 3,61 & 1,108 \\
AT9 & 80 & 3 & 5 & 3,90 &, 789 \\
AT10 & 80 & 3 & 5 & 4,56 &, 548 \\
AT11 & 80 & 2 & 5 & 4,30 &, 753 \\
AT12 & 80 & 2 & 5 & 3,46 &, 954 \\
AT13 & 80 & 2 & 5 & 3,96 &, 920 \\
AT14 & 80 & 2 & 5 & 3,94 & 1,048 \\
Valid N & 80 & \multicolumn{5}{c}{} \\
(listwise) & 80 & & \\
\hline
\end{tabular}

Sumber : Data Olahan, 2021 
Pada tabel diatas item pernyataan 3, 4, 5, 6 menunjukkan bahwa mahasiswa tidak setuju bahwa komputer akan menggantikan peran manusia dan nilai kehidupan masyarakat dan akan membahayakan kehidupan. Hasil ini juga menunjukkan bahwa beberap item pernyataan 10, 11, $12,13,14$ yang hasilnya $>3$, menujukkan penggunaan komputer akan meningkatkan standar hidup manusia dan komputer akan mengeliminasi atau menggantikan pekerjaan yang banyak dan membosankan.

Tabel 3.5

Descriptive Statistics variabel Computer Self Efficacy

\begin{tabular}{cccccc}
\hline & $\mathrm{N}$ & Minimum & Maximum & Mean & Std. Deviation \\
\hline SE1 & 80 & 1 & 5 & 3,35 & 1,137 \\
SE2 & 80 & 2 & 5 & 3,91 &, 845 \\
SE3 & 80 & 1 & 5 & 2,89 & 1,467 \\
SE4 & 80 & 1 & 5 & 2,43 & 1,465 \\
SE5 & 80 & 1 & 5 & 2,59 & 1,420 \\
SE6 & 80 & 2 & 5 & 3,99 &, 849 \\
SE7 & 80 & 1 & 5 & 3,39 & 1,217 \\
SE8 & 80 & 1 & 5 & 3,51 & 1,273 \\
Valid N & 80 & & & & \\
(listwise) & & & & & \\
\hline
\end{tabular}

Sumber : Data Olahan, 2021

Pada tabel 3.6 dapat disimpulkan bahwa mahasiswa memiliki keyakinan terhadap kemampuan yang dimiliki dalam menggunakan dan melaksanakan tugas dengan menggunakan komputer dengan baik.

Tabel 3.6

Descriptive Statistics Kondisi Yang Memfasilitasi Pemakai

\begin{tabular}{cccccc}
\hline & $\mathrm{N}$ & Minimum & Maximum & Mean & Std. Deviation \\
\hline KP1 & 80 & 2 & 5 & 4,01 &, 834 \\
KP2 & 80 & 2 & 5 & 4,01 &, 879 \\
KP3 & 80 & 2 & 5 & 3,76 &, 903 \\
KP4 & 80 & 2 & 5 & 3,82 & 1,003 \\
\hline Valid N & 80 & \multicolumn{5}{c}{} \\
(listwise) & \multicolumn{5}{c}{ Sumber : Data Olahan, 2021 } \\
\hline
\end{tabular}

Pada tabel 3.7 menujukkan hasil yang secara rata-rata $>3$, hasil ini menujukkan responden berupa mahasiswa setuju adanya infrastruktur seperti hardware, software, dll untuk dapat menggunakan software akuntansi itu sendiri dalam proses pembelajaran.

Tabel 3.7

Descriptive Statistics Variabel Faktor Sosial

\begin{tabular}{cccccc}
\hline & $\mathrm{N}$ & Minimum & Maximum & Mean & Std. Deviation \\
\hline FS1 & 80 & 2 & 5 & 4,34 &, 779 \\
FS2 & 80 & 1 & 5 & 4,13 & 1,084 \\
FS3 & 80 & 3 & 5 & 4,66 &, 594 \\
FS4 & 80 & 2 & 5 & 4,52 &, 693 \\
FS5 & 80 & 1 & 5 & 3,62 & 1,226 \\
FS6 & 80 & 2 & 5 & 4,05 & 1,005 \\
\hline Valid N & \multirow{2}{*}{80} & & & & \\
(listwise) & & & & & \\
\hline
\end{tabular}

Sumber : Data Olahan, 2021

Dari tabel 3.7 dapat dilihat bahwa setiap item faktor sosial secara rata-rata $>3$ atau mendekati 4 sehingga dapat disimpulkan bahwa mahasiswa mendapatkan dukungan atau pengaruh dari lingkungan sosialnya sehubungan dengan penggunaan software akuntansi dalam proses pembelajaran akuntansi

\section{Uji Validitas}


Uji validitas ini menggunakan 80 responden untuk menguji 58 pernyataan valid atau tidak valid. Dari 58 pernyataan ada 8 pernyataan yang tidak valid yaitu, sebanyak 7 item pernyataan dari pernyataan variabel computer anxiety, dan 1 item pernyataan dari pernyataan variabel computer attitude. Item pernyataan yang tidak valid tidak diikutsertakan dalam uji selanjutnya.

\section{Uji Reliabilitas}

Cronbach's Alpha variabel Minat Menggunakan Software Akuntansi sebesar 0,780, Computer Anxiety sebesar 0,807, Computer Attitude sebesar 0,797, Computer Self Efficacy sebesar 0,911, Kondisi yang memfasilitasi sebesar 0,903, dan faktor sosial sebesar 0,765 yang berarti Internal consistency reliabilitasnya baik.

\section{Uji Normalitas}

Uji normalitas bertujuan untuk menguji apakah variabel terikat dan variabel bebas dalam model regresi mempunyai distribusi normal atau tidak. Uji normalitas dilakukan terbelih dahulu sebelum melakukan regresi linear berganda.Uji normalitas dilaksanakan agar mengetahui populasi berdistribusi normal atau tidak. Uji normalitas menggunakan kolmogorovSmirnov test. Berikut hasil kolmogorov-Smirnov test:

Tabel 3.8

\begin{tabular}{|c|c|c|}
\hline \multirow{2}{*}{\multicolumn{2}{|c|}{ One-Sample Kolmogorov-Smirnov Test }} & \multirow[b]{2}{*}{$\begin{array}{c}\text { Unstandardized } \\
\text { Residual }\end{array}$} \\
\hline & & \\
\hline $\bar{N}$ & & 80 \\
\hline Normal Parameterca,b & Mean & ,0000000 \\
\hline Thomal $r$ aldineters & $\begin{array}{l}\text { Std. Deviation } \\
\text { Absolute }\end{array}$ & $\begin{array}{c}2,91595747 \\
, 098\end{array}$ \\
\hline Most Extreme Differences & Positive & 095 \\
\hline & Negative &,- 098 \\
\hline Test Statistic & & 098 \\
\hline Asymp. Sig. (2-tailed) & & ,054c \\
\hline
\end{tabular}
a. Test distribution is Normal.
b. Calculated from data.
c. Lilliefors Significance Correction.

Berdasarkan tabel diatas, nilai Asymp Sig yaitu sebesar 0,054. Hal ini menunjukkan nilai signifikan $>0,05$ sehingga dapat disimpulkan bahwa data terdistribusi normal.

\section{Pengujian Uji Hipotesis}

Pengujian hipotesis menggunakan analisis regresi untuk menguji hipotesis yang telah diajukan antara variabel independen (computer anxiety, computer attitude, computer self efficacy, kondisi yang memfasilitasi pemakai, faktor sosial) terhadap variabel dependen (minat mahasiswa menggunakan software akuntansi). Berikut hasil uji $F$

\begin{tabular}{|c|c|c|c|c|c|c|}
\hline \multicolumn{7}{|c|}{ ANOVA $^{a}$} \\
\hline & Model & $\begin{array}{l}\text { Sum of } \\
\text { Squares }\end{array}$ & df & Mean Square & $\mathbf{F}$ & Sig. \\
\hline \multirow[t]{3}{*}{$\overline{1}$} & Regression & 362,228 & 5 & 72,446 & 7,981 &, $000^{\mathrm{b}}$ \\
\hline & Residual & 671,722 & 74 & 9,077 & & \\
\hline & Total & 1033,950 & 79 & & & \\
\hline
\end{tabular}

a. Dependent Variable: Minat menggunakan software akuntansi

b. Predictors: (Constant), Faktor sosial, compter anxiety, computer attitude, computer self efficacy, kondisi yang memfasilitasi 
Hasil uji pada tabel diatas didapat nilai $F$ hitung sebesar 7,981 dengan probabilitas 0,000 . Hal dapat disimpulkan bahwa variabel independen dalam hal ini yaitu computer anxiety, computer attitude, computer self efficacy, kondisi yang memfasilitasi pemakai, dan faktor sosial bersamasama memiliki pengaruh terhadap minat mahasiswa menggunakan software akuntansi.

Uji t dilakukan untuk melihat pengaruh secara parsial variabel indepeden terhadap variabel dependen. Hasil pengujian dapat dilihat pada tabel berikut:

Tabel 4. Hasil uji t

\begin{tabular}{|l|l|c|c|l|}
\hline No. & \multicolumn{1}{|c|}{ Variabel } & Sig & $\%$ & Keterangan \\
\hline 1. & Computer anxiety & 0,584 & 0,05 & Ha Ditolak \\
2. & Computer attitude & 0,050 & 0,05 & Ha Diterima \\
3. & Computer self efficacy & 0,000 & 0,05 & Ha Diterima \\
4. & Kondisi yang memfasilitasi & 0,000 & 0,05 & Ha Diterima \\
5. & Faktor Sosial & 0,352 & 0,05 & Ha Ditolak \\
\hline
\end{tabular}

Sumber : data olahan SPSS, 2021

Berdasarkan hasil uji t pada tabel diatas dapat disimpulkan :

1. Variabel computer anxiety tidak memiliki pengaruh terhadap minat mahasiswa menggunakan software akuntansi. Hal ini dapat dilihat output hasil SPSS, variabel computer anxiety memiliki tingkat signifikan 0,584 >0,05

2. Variabel computer attitude memiliki pengaruh terhadap minat mahasiswa menggunakan software akuntansi. Hal ini dapat dilihat output hasil SPSS, variabel computer attitude memiliki tingkat signifikan 0,05

3. Variabel computer self efficacy memiliki pengaruh terhadap minat mahasiswa menggunakan software akuntansi. Hal ini dapat dilihat output hasil SPSS, variabel computer self efficacy memiliki tingkat signifikan $0,000<0,05$

4. Variabel kondisi memfasilitasi pemakai memiliki pengaruh terhadap minat mahasiswa menggunakan software akuntansi. Hal ini dapat dilihat output hasil SPSS, variabel kondisi memfasilitasi pemakai memiliki tingkat signifikan 0,000 $<0,05$

5. Variabel faktor sosial tidak memiliki pengaruh terhadap minat mahasiswa menggunakan software akuntansi. Hal ini dapat dilihat output hasil SPSS, variabel faktor sosial memiliki tingkat signifikan $0,352>0,05$

Dari hasil uji diatas dapat diketahui bahwa kecemasan mahasiswa adanya komputer tidak menurunkan minat mahasiswa dalam menggunakan software akuntansi dalam proses pembelajaran. Kehadiran komputer dan kondisi yang memfasilitasi pemakan (mahasiswa) dalam proses pembelajaran dengan menggunakan software akuntansi membuat mahasiswa yakin akan memberikan hasil yang lebih baik kedepannya dalam proses pembelajaran khususnya dalam menghadapi persaingan dimasa akan mendatang.

\section{KESIMPULAN}

Berdasarkan hasil penelitian, maka dapat diambil kesimpulan sebagai berikut :

1. Computer Anxiety tidak berpengaruh minat mahasiswa menggunakan software akuntansi. Hasil ini menunjukkan kecemasan mahasiwa adanya komputer tidak menurunkan minat mahasiswa dalam menggunakan software akuntansi.

2. Computer Attitude memiliki pengaruh terhadap minat mahasiswa menggunakan software akuntansi. Hal ini menujukkan mahasiswa merespon positif adanya penggunaan software akuntansi dalam proses pembelajaran akuntansi yang ditandai meningkatnya minat mahasiswa menggunakan software akuntansi dalam proses pembelajaran. 
3. Computer Self Efficacy memiliki pengaruh terhadap minat mahasiswa menggunakan software akuntansi. Hasil ini menunjukkan mahasiswa meyakini kemampuan nya dalam menggunakan komputer sehingga mendorong untuk menggunakan software akuntansi itu sendiri.

4. Kondisi yang memfasilitasi pemakai berpengaruh terhadap minat menggunakan software akuntansi. Hasil ini menujukkan bahwa infrastruktur sarana dan prasarana dalam proses pembelajaran akan berpengaruh terhadap minat mahasiswa menggunakan software akuntansi itu sendiri dalam proses pembelajaran.

5. Faktor sosial tidak berpengaruh terhadap minat mahasiswa menggunakan software akuntansi. Hasil ini menunjukkan bahwa mahasiswa orang lain yang penting tidak mempengaruhi minat mahasiswa dalam menggunakan software akuntansi.

Berdasarkan kesimpulan diatas, maka saran-saran yang dapat diberikan terkait pengaruh computer anxiety, computer attitude, computer self efficacy, kondisi yang memfasilitasi, dan faktor sosial terhadap minat mahasiswa menggunakan software akuntansi dalam proses pembelajaran yaitu :

1. Penggunakan software akuntansi dalam proses pembelajaran akuntansi harus dimulai dilakukan karena mahasiswa khususnya membutuhkan sesuatu yang baru dalam proses pembelajaran sehingga ilmu teori langsung dapat dipraktikkan dalam penggunaan software akuntansi tersebut

2. Tersedianya sarana prasarana yang memadai untuk menunjang pembelajaran berbasis komputer khususnya penggunaan komputer akuntansi disetiap mata kuliah studi akuntansi.

\section{REFERENCES}

[1] Ajzen, I., 2002, Perceived Behavioral Control, Self-Efficacy, Locus of Control, and the Theory of Planned Behavior, Journal of Applied Social Psychology, Vol. 32, pp.665-683.

[2] Davis, Fred D., Richard P. Bagozzi, and Paul R. Warshaw, 1989, User Acceptance of Computer Technology: A Comparison of Two Theorical Models, Management Science, Vol.39, No.8, pp. 983-1003.

[3] Goodhue and Thompson, 1995, Task Technology Fit and Individual Performance, MIS Quartely, June, pp 213236.

[4] Thompson, R.L., Higgins, C.A., and Howell, J.W. 1991, "Personal Computing: Toward T a Conceptual Model of Utilization," MIS Quarterly, March, Vol.15, No.1, pp.124-143.

[5] Ghozali, Imam. (2011). Aplikasi Analisis Multivariate dengan Program IBM SPSS 19. Edisi 5. Semarang: Badan Penerbit Universitas Diponegoro

[6] Irvan Nir Sudibyanto. (2013). "Pengaruh Computer Anxiety, Computer Attitude dan Computer Self Efficacy Terhadap Minat Dalam Berbisnis Secara Online Pada Mahasiswa Akuntansi Fakultas Ekonomi Universitas Negeri Yogyakarta". Skripsi. Program Studi Akuntansi Universitas Negri Yogyakarta.

[7] Indriantoro, Nur. "Pengaruh computer anexiety terhadap keahlian dosen dalam penggunaan komputer." Jurnal Akuntansi dan Auditing Indonesia 4.2 (2000): 191-209.

[8] Putra, F. D. (2021). Pengaruh Computer Anxiety, Computer Attitude, Dan Computer Self Efficacy Terhadap Minat Mahasiswa Akuntansi Menggunakan Software Akuntansi (Studi Kasus pada Mahasiswa Program Studi Akuntansi Fakultas Ekonomi dan Bisnis Universitas Pembangunan Nasional "Veteran" Yogyakarta) (Doctoral dissertation, Universitas Pembangunan Nasional "Veteran" Yogyakarta).

[9] Parasara, Anak Agung Putra. "Pengaruh Computer Anxiety pada Computer Self Efficacy." E-Jurnal Akuntansi Universitas Udayana 2.7 (2014): 289-98.

[10] Handayani, Rini. "Analisis Pengaruh Computer Anxiety dan Self Efficacy terhadap Keahlian Penggunaan Internet pada Mahasiswa." Riset Manajemen dan Akuntansi STIE Atma Bhakti 1.2 (2010): 221161. 
[11] Kuntardi, Dhandhung Budi. "Pengaruh computer Anxiety dan computer Attitude terhadap keahlian Akuntan pendidik dalam menggunakan komputer." (2004).

[12] Maharani, Putu Nirmala. "Pengaruh Computer Anxiety Dan Computer Attitude Terhadap Keahlian Pemakaian Software Akuntansi Pada Mahasiswa Jurusan Akuntansi Di Universitas Mahasaraswati Denpasar." JSAM (Jurnal Sains, Akuntansi dan Manajemen) 1.2 (2019): 236-270.

[13] Putra, Farhan Drijantara. Pengaruh Computer Anxiety, Computer Attitude, Dan Computer Self Efficacy Terhadap Minat Mahasiswa Akuntansi Menggunakan Software Akuntansi (Studi Kasus pada Mahasiswa Program Studi Akuntansi Fakultas Ekonomi dan Bisnis Universitas Pembangunan Nasional "Veteran" Yogyakarta). Diss. Universitas Pembangunan Nasional "Veteran" Yogyakarta, 2021.

[14] Kawedar, Warsito, Rr Sri Handayani, and DUL MUID. "Pengaruh Computer Anxiety dan Math Anxiety Terhadap Keahlian Auditor Dalam Penggunaan Komputer." (2003). 